\title{
X-linked congenital generalized hypertrichosis
}

INSERM

\section{Source}

INSERM. (1999). Orphanet: an online rare disease and orphan drug data base. $\underline{X-l i n k e d}$ congenital generalized hypertrichosis. ORPHA:79495

X-linked cong enital generalized hypertrichosis is an extremely rare type of hypertrichosis lanuginosa congenita, a congenital skin disease, which is characterized by hair overg rowth on the entire body in males, and mild and asymmetric hair overgrowth in females. It is associated with a mild facial dysmorphism (anterverted nostrils, moderate prognathism), and, in a kindred, it was also associated with dental anomalies and deafness. 